DOC.20060918.0007

QA: QA

TWP-NBS-GS-000005 REV 01

September 2006

\title{
Technical Work Plan for: Fracture and Lithophysal Studies
}

Prepared for:

U.S. Department of Energy

Office of Civilian Radioactive Waste Management

Office of Repository Development

1551 Hillshire Drive

Las Vegas, Nevada 89134-6321

Prepared by:

Bechtel SAIC Company, LLC

1180 Town Center Drive

Las Vegas, Nevada 89144

Under Contract Number

'DE-AC28-01RW12101 


\section{DISCLAIMER}

This report was prepared as an account of work sponsored by an agency of the United States Government. Neither the United States Government nor any agency thereof, nor any of their employees, nor any of their contractors, subcontractors or their employees, makes any warranty, express or implied, or assumes any legal liability or responsibility for the accuracy, completeness, or any third party's use or the results of such use of any information, apparatus, product, or process disclosed, or represents that its use would not infringe privately owned rights. Reference herein to any specific commercial product, process, or service by trade name, trademark, manufacturer, or otherwise, does not necessarily constitute or imply its endorsement, recommendation, or favoring by the United States Government or any agency thereof or its contractors or subcontractors. The views and opinions of authors expressed herein do not necessarily state or reflect those of the United States Government or any agency thereof. 


\section{Technical Work Plan for: Fracture and Lithophysal Studies TWP-NBS-GS-000005 REV 01 \\ September 2006}




\section{INTENTIONALLY LEFT BLANK}


Bechtel SAIC Company, LLC

Technical Work Plan for:

FRACTURE AND LITHOPHYSAL STUDIES

TWP-NBS-GS-000005 REV 01

September 2006

Prepared by:

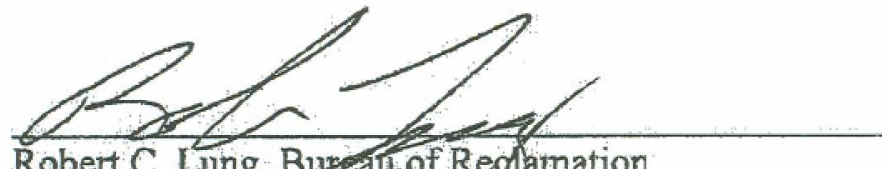

Robert C. Lung, Buyedil of Redlamation

Technical Woet Tlan Manager

Approved by:

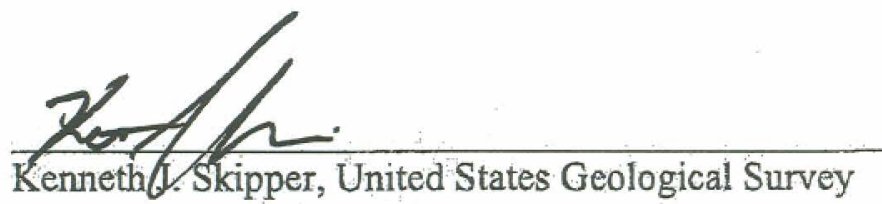

Yucca Mountain Project Branch Chief

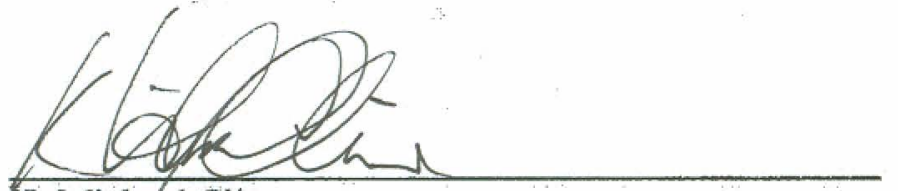

K. Michael Cline

Department Manager, Bechtel SAIC Company

Postclosure Activities, Disruptive Events
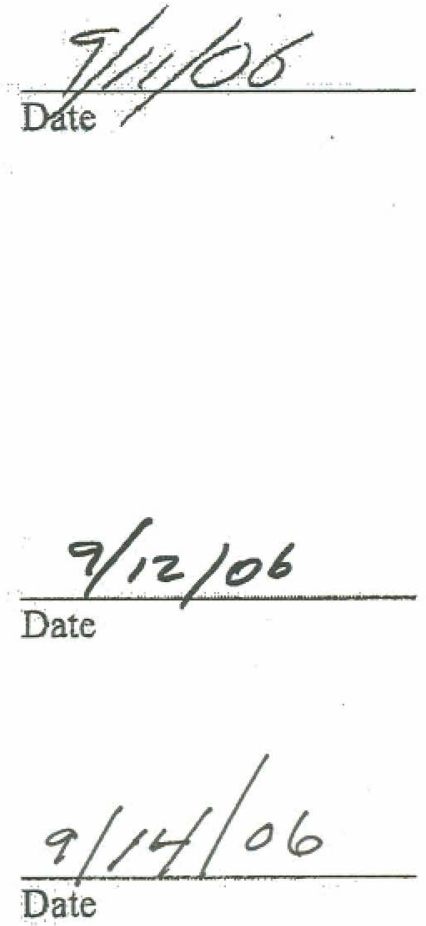


\section{CHANGE HISTORY}

\begin{tabular}{|c|c|c|c|}
\hline $\begin{array}{l}\text { Revision } \\
\text { Number }\end{array}$ & $\begin{array}{l}\text { ICN } \\
\text { Number }\end{array}$ & $\begin{array}{l}\text { Date of } \\
\text { Change }\end{array}$ & Description of Change \\
\hline 00 & 00 & $11 / 14 / 2002$ & Initial issue \\
\hline 01 & 00 & $9 / 11 / 2006$ & $\begin{array}{l}\text { Revision } 01 \text { addresses substantive work scope } \\
\text { changes, including the planning requirements for } \\
\text { development and validation of a new model and } \\
\text { documentation in a model report. The TWP also } \\
\text { describes impact evaluation activities for those } \\
\text { products that currently rely on related data. The } \\
\text { revision also updates the planning document format } \\
\text { following new procedural requirements in LP-2.29Q- } \\
\text { BSC. The changes made to this TWP represent a } \\
\text { complete revision; therefore, change bars are not } \\
\text { shown in the document. This revision supersedes } \\
\text { TWP-NBS-GS-000005 REV 00, Technical Work Plan } \\
\text { for: Fracture and Lithophysal Studies. }\end{array}$ \\
\hline
\end{tabular}




\section{CONTENTS}

Page

ACRONYMS $\mathrm{xi}$

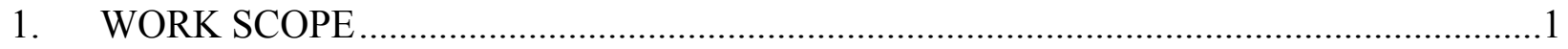

$1.1 \quad$ OVERALL OBJECTIVE......................................................................... 1

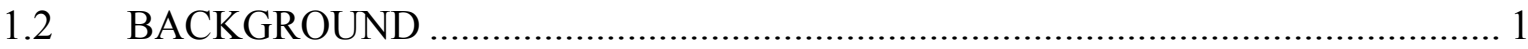

1.3 MAJOR WORK ACTIVITIES AND PRODUCTS …......................................... 3

1.4 ORGANIZATIONS PERFORMING THE WORK ….......................................... 3

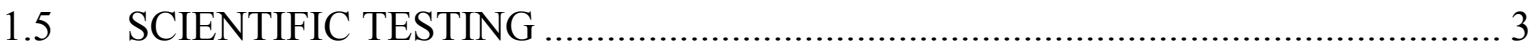

2. SCIENTIFIC APPROACH OR TECHNICAL METHODS …….......................................

$2.1 \quad$ INTENDED USE OF PRODUCTS ................................................................ 4

2.2 SCIENTIFIC APPROACH AND TECHNICAL METHODS ................................ 4

2.2.1 Assemble Appropriate Existing Data and Synthesize …………......................... 4

2.2.2 Development of a Discrete Fracture Network Model for the RHH..................... 4

2.2.3 Validation Activities during Model Development............................................... 5

2.2.4 Qualification of FRACMAN XP ............................................................. 5

2.2.5 Implement Model and Perform Analyses ………….......................................... 5

2.2.6 Document the Work................................................................................... 5

2.2.7 Submit Developed Parameter Values and Expected Bounds to the TDMS ........ 6

2.3 UNEXPECTED TEST RESULTS, TEST CONDITIONS, OR OFF-NORMAL

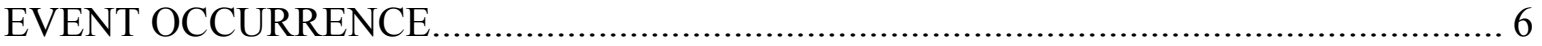

2.4 FEATURES, EVENTS AND PROCESSES ……................................................. 6

2.5 ADDITIONAL MODELING AND SCIENTIFIC ANALYSIS ACTIVITIES ........ 7

2.5.1 Validation Activities during Model Development............................................... 7

2.5.2 Required Level of Confidence in Postdevelopment Model Validation................ 7

2.5.3 Justification for Model Validation................................................................... 8

2.5.4 Review Sessions for Model Validation Quality Issues ....................................... 9

2.5.5 Model Validation Criteria .............................................................................. 9

2.5.6 Scientific Analysis Using Previously Developed and Validated Models............ 9

2.5.7 Validation Plans for Models Used Outside Current Validation Range ............... 9

3. INDUSTRY STANDARDS, FEDERAL REGULATIONS, DOE ORDERS, REQUIREMENTS, AND ACCEPTANCE/COMPLETION CRITERIA …………...........10

3.1 TECHNICAL AND INDUSTRY STANDARDS ............................................ 10

3.2 REGULATORY REQUIREMENTS.............................................................. 10

3.3 ACCURACY, PRECISION, AND REPRESENTATIVENESS OF RESULTS .... 10

3.4 ACCEPTANCE/COMPLETION CRITERIA ………………………………... 10

3.5 OTHER REQUIREMENTS …………………............................................ 11

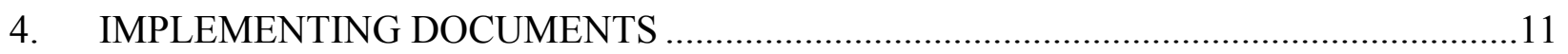

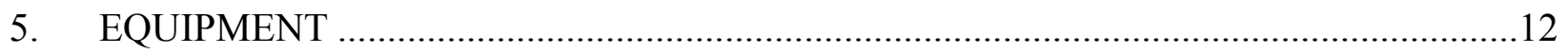




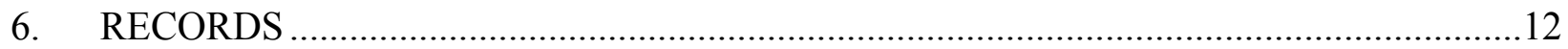

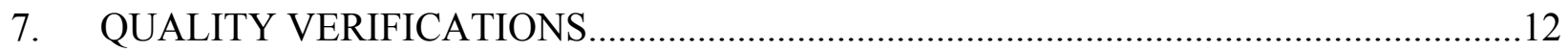

8. PREREQUISITES, SPECIAL CONTROLS, ENVIRONMENTAL CONDITIONS,

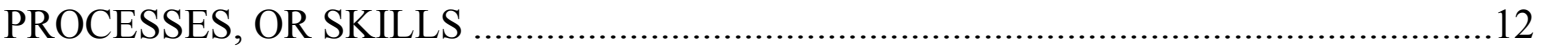

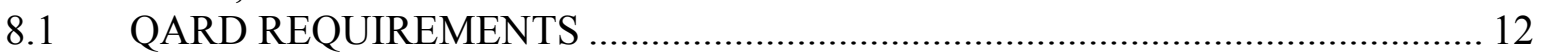

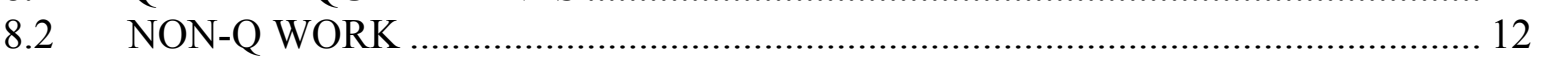

8.3 WORK PREREQUISITES ............................................................................... 13

8.4 ELECTRONIC MANAGEMENT OF INFORMATION (IT-PRO-0009)............... 13

8.5 GENERAL TRAINING/QUALIFICATION REQUIREMENTS .......................... 14

8.6 ENVIRONMENTAL CONTROLS................................................................. 14

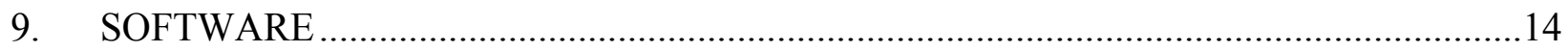

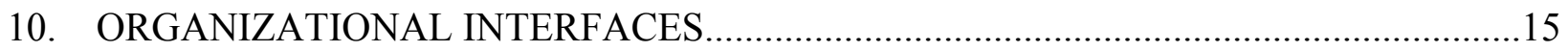

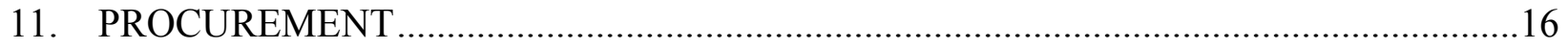

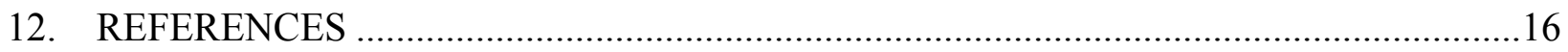

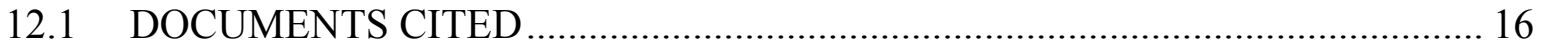

12.2 CODES, STANDARDS, REGULATIONS, AND PROCEDURES ........................ 18

APPENDIX A SOURCE DATA, LISTED BY DATA TRACKING NUMBER ................. A-1

APPENDIX B PLANNING FOR TECHNICAL REVIEWS FOR PURPOSES

OF MODEL VALIDATION ……………………………………….........

APPENDIX C YMRP ACCEPTANCE CRITERIA APPLICABLE TO

ACTIVITIES RELATED TO TWP-NBS-GS-000005 …………………….....

APPENDIX D PROCESS CONTROL EVALUATION FOR THE

ELECTRONIC MANAGEMENT OF INFORMATION............................. D-1 


\section{TABLES}

Page

1. Summary of Software Used to Support Fracture and Lithophysal Studies ........................14 


\section{INTENTIONALLY LEFT BLANK}




\section{ACRONYMS}

AIN additional information needs

ASTM American Society for Testing and Materials International

BSC

Bechtel SAIC Company, LLC

BOR

Bureau of Reclamation

DOE

U.S. Department of Energy

FEP features, events, and processes

KTI key technical issue

NRC U.S. Nuclear Regulatory Commission

RHH repository host horizon

SDS Structural Deformation and Seismicity

TDMS Technical Data Management System

TSPA total system performance assessment

TWP technical work plan

USGS U.S. Geological Survey

YMP Yucca Mountain Project 


\section{INTENTIONALLY LEFT BLANK}




\section{WORK SCOPE}

\subsection{OVERALL OBJECTIVE}

The primary objective of the work scope described in this technical work plan (TWP) is to enhance the descriptions of fracture and lithophysal parameters for the repository host horizon $(\mathrm{RHH})$ over the repository footprint utilizing a predictive model. This work is planned to address U.S. Nuclear Regulatory Commission (NRC) additional information needs (AINs) associated with the Structural Deformation and Seismicity (SDS) Key Technical Issues (KTI) agreement SDS 3.03 (Schlueter 2000 [DIRS 166615]). The results of the planned work are expected to enhance the technical basis and confirm the results of the fracture analyses presented in Drift Degradation Analysis (BSC 2004 [DIRS 166107], Section 6.1.6). This model is not intended to provide an alternative for the unsaturated zone and saturated zone flow and transport models currently used by the Yucca Mountain Project (YMP). Nor are the outputs of this model intended to address the SDS 3.03 AINs related to the unsaturated zone and saturated zone flow and transport models.

\subsection{BACKGROUND}

The U.S. Department of Energy (DOE) submitted Fracture Geometry Analysis for the Stratigraphic Units of the Repository Host Horizon (CRWMS M\&O 2000 [DIRS 152286]) to the $\mathrm{NRC}$ for review and comment. The NRC determined that the information contained in the report was not sufficient to conduct a licensing review and requested additional information (Reamer 2001 [DIRS 177158]; McKague 2000 [DIRS 177187]) in the form of eight items of information that were necessary to support a licensing review:

- Item 1 DOE needs to: (i) provide a technical basis for DOE'S conclusion that fracture geometry parameter values for the repository host horizon are correct; (ii) provide a set of data corrected for these sampling biases along with a description of the methodology used for sampling bias correction; or (iii) risk-inform its results.

- Item 2 DOE needs to provide a technical basis or rationale to support its extrapolation of fracture parameters to the repository footprint area that accounts for heterogeneities in the repository host horizon and uncertainties in the fracture characteristics and their distribution. This rationale should support models and calculations used to select the new emplacement drift alignment and for the key block analyses underway. Similarly, rationales should be developed to support the use of the active fracture model and calculations that import or abstract fracture spacing data from the repository host horizon fracture analysis model report. Alternatively, DOE would need to develop other viable fracture models and assess the range of results derived from consideration of the assumptions of variability and uncertainties or otherwise risk-inform its current extrapolation.

- Item 3 DOE needs to provide a technical basis or rationale or both for its selection of fracture sets (i.e., sets based on orientation and lithology, rather than on origin) and provide statistics that represent the parameter distributions within each fracture set or risk-inform the aggregated characteristics.

- Item 4 DOE needs to provide a technical basis or rationale or both for using a fracture-length database for various rockfall analyses and other calculations that is truncated at $1 \mathrm{~m}[3.3 \mathrm{ft}]$. 
This rationale should be provided to support DOE's key block analyses for the lower lithophysal unit of the Topopah Spring Tuff (Tptpll) that are underway. Alternatively, DOE could riskinform the fracture-length database.

- Item 5 DOE needs to describe the procedure for defining sets, explain the use of single-value orientations to represent fracture set mean orientations, provide statistics that represent the range or variation in orientation distribution within each fracture set, or risk-inform the fracture-orientation variation database.

- Item 6 DOE needs to provide: (i) a technical basis for the method it used to measure fracture lengths in tunnels and drifts to support its conclusions; (ii) an assessment of the potential fracture shapes and their significance, if any, to performance; or (iii) risk-inform the results of DOE's fracture trace length and fracture shape data and assumptions.

- Item 7 DOE needs to provide, in a transparent format, a distribution of orientations and related population statistics for subhorizontal fractures that it used or assumed for tunnel stability analysis or risk-inform the current uses or assumptions.

- Item 8 DOE needs to provide a population statistical analysis-unit by unit, set by set-of the fracture data and results and provide the character statistics or risk-inform the current assumption.

The DOE (Brocoum 2001 [DIRS 177163]; Ziegler 2002 [DIRS 177162]) indicated that the information to address the eight AINs would be addressed in a planned fracture synthesis report, but that portions of AINs 5 and 6 would be addressed in a planned revision to Drift Degradation Analysis (BSC 2004 [DIRS 166107])

The NRC (Kokajko 2005 [DIRS 177157]) considers that KTI Agreement SDS 3.03 (Schlueter 2000 [DIRS 166615]) has not been adequately addressed by the DOE. The NRC reviewed Drift Degradation Analysis (BSC 2004 [DIRS 166107]) and determined that information in the report did not provide responses that specifically addressed any of the AIN items, including items 5 and 6. The NRC also noted that the planned fracture analysis report had not been submitted to the NRC.

The planned work described in this TWP synthesizes existing data on repository host horizon fractures in lithophysal and nonlithophysal rocks, develops and implements a predictive model of fracture characteristics in the $\mathrm{RHH}$, and documents this information in a model report to be entitled Fracture and Lithophysal Characteristics of the Repository Host Horizon Zones.

In addition, the results of the work described in this TWP will enhance the technical basis for fracture analyses presented in Drift Degradation Analysis (BSC 2004 [DIRS 166107], Section 6.1.6, Appendix B). Fracture analyses reported in Drift Degradation Analysis (BSC 2004 [DIRS 166107]) form a subset of the overall fracture analyses that will be documented in the model report. Documentation of these results is expected to confirm the analyses documented in Drift Degradation Analysis (BSC 2004 [DIRS 166107]) and provide additional traceability and transparency for the data and analysis results. 


\subsection{MAJOR WORK ACTIVITIES AND PRODUCTS}

The major work activities and products are:

1) Assembly of the appropriate existing data

2) Development of a discrete fracture network model for the RHH

3) Verification and validation of the model

4) Qualification of a new version of software item FRACMAN XP

5) Documentation of the work effort in the form of reports

6) Submittal of developed parameter values and expected bounds to the Technical Data Management System (TDMS), per the requirements of AP-SIII.3Q, Submittal and Incorporation of Data to the Technical Data Management System.

Fracture and lithophysae data have been collected from the repository host horizon. Fracture data include: the detailed line survey data submitted by the U.S. Geological Survey (USGS)/ U.S. Bureau of Reclamation (BOR) as a result of underground mapping activities; data from the fracture information recorded on the full-periphery geologic maps; data from existing boreholes of the YMP; and fracture data from the surface mapping of the repository host horizon. Data to be considered in developing the model are described in 36 data packages (DTNs). A list of the DTNs is provided in Appendix A. The data packages are archived in the Technical Data Management System (TDMS).

The fracture data will be separated into sets and the statistical properties of fracture parameters rock unit-by-rock unit and set by set will be developed from the data. Fracture parameters to be developed are orientation, length, truncation, frequency, and fracture shape. Estimates of expected bounds for fracture parameters over the repository footprint will be made. The lithophysal data will be used to develop a characterization of the lithophysal distributions and textures within the RHH over the repository footprint.

\subsection{ORGANIZATIONS PERFORMING THE WORK}

USGS and BOR individuals will perform the analyses and modeling of fracture and lithophysae data from the RHH. It is anticipated that subcontracted personnel will assist in software qualification and independent technical review tasks. The Bechtel SAIC, LLC (BSC) Postclosure Activities-Disruptive Events department will support planning, integration, and review of the work and draft documentation.

\subsection{SCIENTIFIC TESTING}

As this is not a testing activity, no pretest predictions are required for work described by this TWP. 


\section{SCIENTIFIC APPROACH OR TECHNICAL METHODS}

\subsection{INTENDED USE OF PRODUCTS}

Three items comprise the products of this activity: (1) a discrete fracture network model data submittal to the TDMS, (2) a model report describing the discrete fracture network model, and (3) a USGS report documenting the work. Items 1 and 2 will be used to support the description in the license application of fractures in the RHH at the site, specifically addressing the eight NRC AINs. Item 3 will be used as the basis for obtaining USGS Director's approval of the work.

\subsection{SCIENTIFIC APPROACH AND TECHNICAL METHODS}

\subsubsection{Assemble Appropriate Existing Data and Synthesize}

Fracture and lithophysal data will be assembled from the TDMS to begin reducing data. Data will be reduced into various subsets to begin defining bounds and parameters of $\mathrm{RHH}$ fracture and lithophysae.

As in Drift Degradation Analysis (BSC 2004 [DIRS 166107]), a hierarchical approach to defining fracture genesis and distribution will be employed. This approach examines the rocks in a beginning-to-end time line and lends itself to an evaluation that results in the real world representation of fracture formation and distribution.

Modeling of fractures in the lithophysal zone requires an understanding of the role of the lithophysae. To accomplish this analysis, the current thermal conductivity model of the repository horizon (BSC 2004 [DIRS 169854]) will be evaluated and a geologic interpretation of the porosity distribution will be developed. Once a distribution of lithophysae (porosity) is developed then fractures can be modeled for the various lithophysae concentrations in the lithophysal zones of the Topopah Spring Tuff. Additionally the fracture model report will compile and analyze the lithophysal distribution analysis from the drift degradation analysis (BSC 2004 [DIRS 166107]). Lithophysal data from these two reports along with other borehole and tunnel mapping data will be employed in the analysis of determining the lithophysal distribution and how it governs the creation and population of fractures in lithophysal zones of the Topopah.

\subsubsection{Development of a Discrete Fracture Network Model for the RHH}

Separate the fractures into sets. AINs 3, 5, and 7 will be addressed with this definition of sets. The vertical and subhorizontal fractures are included in these sets. This task will also enhance the technical basis for fracture sets used in Drift Degradation Analysis (BSC 2004 [DIRS 166107]).

Determine the statistical properties of fracture parameters unit-by-unit and set-by-set from these data. The fracture parameters are orientation, length, and aperture. The statistical properties are mean, deviation, and dispersion. AINs 2, 6, and 8 will be addressed by these properties. The censoring and truncation of length will be discussed in this analysis. Item 1 is addressed by a discussion of the bias and its accommodation in the analysis. 
Estimate expected bounds for fracture parameters over the extent of the RHH over the repository footprint. This will be accomplished through the analysis of distribution curves from existing site data and by comparison to analogous known pyroclastic flows.

\subsubsection{Validation Activities during Model Development}

Model validation will be conducted during the development process of the model. The software allows the user to validate modeling results by sampling the model the same way that the input data was sampled. For example, if the input data were collected from a 7-m-diameter tunnel with a given azimuth, then the synthetic is also sampled using a 7-m-diameter tunnel on the same azimuth. This sampling also provides direct validation of the model through the representativeness of the synthetic network. Section 2.5.1 provides further discussion.

\subsubsection{Qualification of FRACMAN XP}

Qualify FRACMAN XP running in the Windows XP operating system. FRACMAN XP is a newer version of the FracMAN tools. Being Windows based in contrast to DOS based, provides the YMP with the capability of handling larger fracture models necessary for a model of the RHH over the repository footprint. The intended use is to provide YMP with an effective software tool that is less limited as to the size of the model that can be generated without relying on a composite model.

\subsubsection{Implement Model and Perform Analyses}

Through the evaluation of fracture property distributions and parameters, modeling inputs will be developed. These inputs will be used to generate a discrete fracture network model of each RHH. These networks will then be compared analytically to the geologic data to evaluate how closely the model represents the actual data. The modeling software allows the user to sample the synthetic in the same manner as the real was sampled. Given the various distributions of data across the footprint of the proposed repository, careful analysis will be conducted to ensure local data is honored while not allowing data-poor areas to be represented in an unrealistic manner. It is possible that many modeling runs will be required to develop a satisfactory fracture network or to generate the statistical foundation to demonstrate that parameter bounds have been addressed.

\subsubsection{Document the Work}

Write, assemble, and approve Fracture and Lithophysal Characteristics of the Repository Host Horizon Zones, in compliance with LP-SIII.10Q-BSC, Models. The report will estimate the fracture and lithophysal parameters for the RHH. It will also include assessments of tectonic effects on discontinuity formation and distribution, and the lithostratigraphy of the RHH. The primary use of this model is to serve as a basis for resolving DOE-NRC KTI agreement AINs and to enhance the technical basis for fracture inputs used in Drift Degradation Analysis (BSC 2004 [DIRS 166107]).

In addition to the report, USGS scientific investigation reports will be written on fracture parameters, tectonic effects on discontinuity formation and distribution, and lithostratigraphy of the RHH. These reports will be subject to USGS Director approval. 


\subsubsection{Submit Developed Parameter Values and Expected Bounds to the TDMS}

Submit to the TDMS, fracture and lithophysal parameters of fracture/fault attitude, fracture/fault frequency, fault location, fault zone width, fracture spacing, lithophysae characteristics, and lithophysae abundance. The intended use is to provide YMP with summary parameters for use in other activities.

Unqualified data necessary for direct input will be qualified in accordance with LP-SIII.2Q-BSC, Qualification of Unqualified Data.

\subsection{UNEXPECTED TEST RESULTS, TEST CONDITIONS, OR OFF-NORMAL EVENT OCCURRENCE}

No tests are associated with this TWP. Off-normal events are not considered likely when performing these activities.

If an off-normal event occurs, the responsible manager will be notified and USGS personnel will investigate the reliability of the findings to ascertain whether results are caused by analysis artifacts or geological phenomena. If unexpected results are determined to be geological in nature, preliminary data or analysis will be discussed with the Technical Work Plan Manager or appropriate discipline lead as it becomes available. In addition, if a geologic condition that differs greatly from expected conditions or a drastic change in geologic conditions encountered is recognized, it will be reported to the Office of Repository Development Field Test Coordinator using AP-REG-009, Reportable Geologic Condition. Conditions that could adversely affect environmental protection, personnel health and safety, or could contribute to conditions adverse to quality will be dealt with according to AP-16.1Q, Condition Reporting and Resolution.

Potential impacts of fracture model results on fracture inputs to Drift Degradation Analysis (BSC 2004 [DIRS 166107]) modeling will be evaluated as part of the technical review of the fracture model. Technical review criteria will include one to specifically assess any impacts of the model of existing results. If an impact is determined, a condition report will be initiated.

An assessment of the potential impacts of the new data, analyses, and modeling results, as described in this TWP, will be performed to identify any significant differences with the input and results from other fracture-informed models, such as those developed in the Natural Systems and Near-Field Environment groups. Notification of potential impacts will be documented either through processes controlled by AP-SIII.3Q, Submittal and Incorporation of Data to the Technical Data Management System, or AP-16.1Q, Condition Reporting and Resolution, as appropriate.

\subsection{FEATURES, EVENTS AND PROCESSES}

The data and analyses do not directly address total system performance assessment features, events, and processes (FEP), although its results are related to FEP1.2.02.01.0A, Fractures. The results of the modeling activities governed by this TWP will be evaluated against the results of products that that contain screening arguments related to this FEP. In addition, results may contribute to the confirmation or further evaluation of FEPs 1.2.02.02.0A, Faults; and 2.2.03.02.0A, Rock Properties of the Host Rock and Other Units (BSC 2005 [DIRS 168706]). 


\subsection{ADDITIONAL MODELING AND SCIENTIFIC ANALYSIS ACTIVITIES}

\subsubsection{Validation Activities during Model Development}

LP-SIII.10Q-BSC requires that models be validated for their intended purpose and stated limitations, and to the level of confidence required by the model's relative importance to the potential performance of the repository system. Activities required by this TWP will result in the development of a model. This model will require validation as noted by LP-SIII.10Q-BSC, Section 5.3.1(f). The model will be validated for its intended use and stated limitations, and to the level of confidence required by the model with respect to its importance to the potential performance of the repository system.

The model validation documentation shall include:

- Identification of corroborating/supporting data, models, or information used to complete model validation activities. Identify the sources of the corroborating/supporting information.

- Level of model importance and required level of confidence.

- Documentation and discussion of model validation activities performed in accordance with LP-SIII.10Q-BSC, Section 5.3.

- Results of the validation activities.

- Model validation criteria explicitly specified for ensuring the appropriate level of confidence has been obtained, consistent with LP-SIII.10Q-BSC, Section 5.3 and this TWP. These criteria must address adequacy of the scientific basis and accuracy of the model consistent with intended use per LP-SIII.10Q-BSC, 5.3.1b)1) and 2).

- Text demonstrating that validation criteria are met consistent with the stated level of confidence required for the model. Any future activities that need to be accomplished for model validation and a justification for extending model validation beyond the documented completion of the current model.

- Because model validation may consist of a sequence of separate activities, each model validation activity should be documented in accordance with the requirements of this procedure upon its completion.

\subsubsection{Required Level of Confidence in Postdevelopment Model Validation}

The fracture model has been determined to require Level I model validation in accordance with LP-SIII.10Q-BSC requirements. LP-2.29Q-BSC, Planning for Science Activities, Attachment 1, states that Level I validation is sufficient for models of less importance to the estimate of mean annual dose. The activities covered in this TWP evaluate fracture and lithophysal parameters for the repository host horizon (RHH) over the repository footprint. The fracture process model addresses NRC KTI open issues and provides further confirmation of the fracture model used in Drift Degradation Analysis (BSC 2004 [DIRS 166107, Section 7.0]. The modeling of fracture 
characteristics within repository horizon lithologic units is considered analogous to other process models over the repository horizon that have little or no affect on mean annual dose.

\subsubsection{Justification for Model Validation}

Level I validation for the fracture model will follow the requirements specified in LP-2.29QBSC. The method of validation from LP-SIII.10Q-BSC, Section 5.3.2 to be applied will be technical review by reviewers independent of the development, checking, and review of the model documentation. Appendix B provides further detail on subject matter expertise and qualifications that will be used as selection criteria in the technical reviewer selection process.

The qualifications of the model validation technical reviewer are:

(a) The reviewer shall not have contributed to the development of model assumptions, parameters, or implementing algorithms.

(b) The reviewer shall have an appropriate technical background (i.e., a degree in geology or strongly related field) and demonstrated expertise in the area addressed by the model.

Qualifications and training of the independent model validation technical reviewer shall be reviewed and approved by a memo to file from the responsible manager.

The model validation technical reviewer shall:

(a) Meet with the document author and representatives from the Igneous Activity organization to obtain a full understanding of the model to be validated, model components, and TSPA implementation.

(b) Review relevant sections of the draft model report that pertain to the model being validated. Evaluate whether the report discussion adequately addresses the requirements listed in Section 2.6.1, providing sufficient confidence in the model with regard to its input parameters, physical principles, assumptions and simplifications, uncertainties, and demonstration of adequacy of its range of use.

(c) Assess whether the model validation criteria to be addressed for models under development have been adequately addressed.

(d) Meet with the author to resolve comments, and recommend actions to resolve any inadequacies found as part of the review.

(e) Document the review process as a memo to record, to be included in the final records package for the respective model report. Any tests, comparisons, or evaluations made to review the model shall be documented. The Igneous Responsible Manager and author will ensure incorporation of the review in the model report and submittal of the records to the YMP Records Processing Center. 


\subsubsection{Review Sessions for Model Validation Quality Issues}

The review sessions of the model validation quality issues to be conducted by the responsible manager with the model report originator, checker, and independent technical reviewer (ITR) will take place prior to each step in the documentation process. The quality review with the originator will be conducted prior to the start of the model report preparation at approximately the time that final model estimates and inputs are developed. The review with the checker will begin prior to the start of checking. The review with the independent technical reviewer will be conducted prior to the beginning of the PA-PRO-0601 document review.

\subsubsection{Model Validation Criteria}

Acceptance Criteria to be Evaluated by the Technical Reviewers

The following criteria will be evaluated by the technical reviewers:

- Is the conceptual model reasonable and appropriate for its intended use?

- For the given inputs, are the outputs reasonable?

- Are limitations of field and analytical data addressed with respect to the conceptual model described?

- Are there other approaches that may enhance the confidence in use of the model?

- Are there other alternative models that should be addressed?

\section{$\underline{\text { Uncertainty }}$}

Comparison of synthetic (model derived) and real (observed) data will be quantitative. Similarity measures between synthetic and real summary statistics of the modeled parameters will be presented. The error match between synthetic and real at specific locations of rich data is within a factor of 2 (mean and standard deviation). As the fracture synthetic data are the result of a stochastic model, reasonable similitude rather than exactness is the criterion. Estimates of parameters in areas of no data should result in reasonable values. Reasonable bounds will be determined for fracture orientation, fracture length, and fracture aperture. The distribution of these parameters will be quantified using similarity measures, such as the Kolmolgorov-Smirnov statistics. There will be a reasonable match between synthetic patterns of fractures and the real patterns as documented by the full periphery geologic maps (real data). A reasonable match will be one in which there is consistency in patterns based on scientific judgment.

\subsubsection{Scientific Analysis Using Previously Developed and Validated Models}

Not applicable. No previously developed and validated models will be used in this activity.

\subsubsection{Validation Plans for Models Used Outside Current Validation Range}

Not applicable. No previously developed models will be used outside of intended use, limitations or range of validity in this activity. 


\section{INDUSTRY STANDARDS, FEDERAL REGULATIONS, DOE ORDERS, REQUIREMENTS, AND ACCEPTANCE/COMPLETION CRITERIA}

\subsection{TECHNICAL AND INDUSTRY STANDARDS}

No industrial or technical standards are directly applicable to the work activities described in this TWP.

\subsection{REGULATORY REQUIREMENTS}

The following requirements from 10 CFR Part 63 [DIRS 173273]) are implemented in these activities through LP-SIII.10Q-BSC. No additional requirements were identified in the Requirements Management System, related to the activities discussed in this TWP.

- 10 CFR 63.21 (b) (1): A general description of the proposed geologic repository at the Yucca Mountain site, identifying the location of the geologic repository operations area, the general character of the proposed activities, and the basis for the exercise of the Commission's [NRC] licensing authority.

- 10 CFR 63.114 (a): Include data related to the geology, hydrology, and geochemistry (including disruptive processes and events) of the Yucca Mountain site, and the surrounding region to the extent necessary, and information on the design of the engineered barrier system used to define parameters and conceptual models used in the assessment.

- 10 CFR 63.114 (b): Account for uncertainties and variabilities in parameter values and provide for the technical basis for parameter ranges, probability distributions, or bounding values used in the performance assessment.

- 10 CFR 63.114 (g): Provide the technical basis for models used in the performance assessment such as comparisons made with outputs of detailed process-level models and/or empirical observations (e.g., laboratory testing, field investigations, and natural analogs).

\subsection{ACCURACY, PRECISION, AND REPRESENTATIVENESS OF RESULTS}

The report and models addressed in this TWP will state the level of accuracy, precision, and representativeness for the results, and how these are determined. Accuracy and precision of the data are specific for each parameter and are controlled by procedures YMP-USGS-GP-20, Estimating Abundance of Features in Core and in Outcrop, Including Lithophysae, Spots, Clasts, and Fractures; YMP-USGS-GP-32, Underground Geologic Mapping; and YMP-USGS-GP-54, Rock Mass Classification, Manual or Electronic. Uncertainties associated with these products are a function of the specific modeling application and should be determined by the use of the specific model and analysis cases. The activities covered by this TWP will meet the level of detail and accuracy needed to support other analysis or model reports and the TSPA model.

\subsection{ACCEPTANCE/COMPLETION CRITERIA}

Acceptance/completion criteria to be implemented are taken from Yucca Mountain Review Plan, Final Report (YMRP) (NRC 2003 [DIRS 163274]). Several attributes of the completion of this 
effort are intended to help resolve AINs associated with KTI agreement SDS 3.03 (Schlueter 2000 [DIRS 166615]) with the NRC (Williams 2002 [DIRS 177159]).

A subset of the acceptance criteria are presented inSections 1.5.3, 2.2.1.3.2.3, and 2.2.1.3.6.3 of the YMRP (NRC 2003 [DIRS 163274]) and are applicable to the activities described in this TWP. A table of the applicable acceptance criteria is provided in Appendix C.

\subsection{OTHER REQUIREMENTS}

This TWP, as well as the model report governed by this TWP, will be DOE deliverables per AP7.5Q, Establishing Deliverable Acceptance Criteria and Submitting and Reviewing Deliverables. Both of these documents will be subject to criteria as described in the associated deliverable definition sheets. No derived requirements have been identified in engineering, performance assessment, or other source documents.

\section{IMPLEMENTING DOCUMENTS}

The following procedures or their replacements will be used to perform any modeling or analysis work, as appropriate, to individual tasks within work packages. No additional implementing documents are planned to be developed to control and perform any activity. All non-Q activities, such as technical scoping activities, will be done per procedures listed below, except for the preparation of the USGS Scientific Investigation Reports discussed in Section 2.2.6. These reports will be developed, approved, and controlled by the USGS under the USGS process governing the development of such reports.

Procedures used to control the work include:

AP-17.1Q, Records Management

AP-SIII.3Q, Submittal and Incorporation of Data to the Technical Data Management System

IT-PRO-0009, Control of the Electronic Management of Information

IT-PRO-0011, Software Management

IT-PRO-0012, Qualification of Software

IT-PRO-0013, Software Independent Verification and Validation

IT-PRO-0015, Software Compliance

PA-PRO-0601, Document Review

LP-2.29Q-BSC, Planning for Science Activities

LP-3.15Q-BSC, Managing Technical Input Products

LP-SIII.2Q-BSC, Qualification of Unqualified Data 


\author{
LP-SIII.10Q-BSC, Models \\ YMP-USGS-GP-20, Estimating Abundance of Features in Core and in Outcrop, Including \\ Lithophysae, Spots, Clasts, and Fractures \\ YMP-USGS-GP-32, Underground Geologic Mapping \\ YMP-USGS-GP-54, Rock Mass Classification, Manual or Electronic.
}

\title{
5. EQUIPMENT
}

Technical products from analysis and modeling activities (analyses, models, reports, and calculations) will be prepared using ordinary office equipment, including project-standard desktop computers. Software will be run on project-standard computers. No field or lab systems will be used; therefore calibration requirements and methods for addressing instrument error are not applicable.

\section{RECORDS}

All records generated as a result of implementing procedures listed in Section 4 of this TWP, will be collected and submitted to the Records Processing Center (RPC) in accordance with the current version of AP-17.1Q, Record Management.

\section{QUALITY VERIFICATIONS}

Personnel working to this TWP will assist with routine audits, surveillances, and selfassessments as appropriate. No mandatory hold points or readiness reviews will be required during the execution of this TWP.

\section{PREREQUISITES, SPECIAL CONTROLS, ENVIRONMENTAL CONDITIONS, PROCESSES, OR SKILLS}

This section discusses Quality Assurance Requirements and Description (QARD), (DOE 2006 [DIRS 176927]); IT-PRO-0009, Control of the Electronic Management of Information; and training requirements as they apply to this work.

\subsection{QARD REQUIREMENTS}

The work scope described in this TWP was determined to be subject to the requirements of the QARD because the work scope involves characterization-related activities, specifically analysis of data and scientific studies that provide data to support preclosure safety analysis, performance confirmation, and TSPA.

\subsection{NON-Q WORK}

Non-Q work associated with this activity may include administrative, editorial, and similar nontechnical activities. The USGS Scientific Investigation Reports will be developed and controlled under USGS processes and procedures, and not per the QARD. Technical scoping activities will include testing of various methods that may be used for analysis of data. Technical scoping 
activities will be performed in compliance with LP-SIII.10Q-BSC. All non-Q activities are subject to the general requirements for planning and control of work activities, per DOE/RW0565, Augmented Quality Assurance Program (AQAP) (DOE 2004 [DIRS 171341]).

\subsection{WORK PREREQUISITES}

Prior to beginning work, the following prerequisites will be met:

- As stated in Sec. 2.4.4, the responsible manager will meet with the originator prior to the origination of the document, per the guidance provided in PA-DSK-0330-1002, Pre-job Briefings.

- All software to be used in support of the modeling activities will be evaluated to ensure that all software codes are qualified and controlled on the software baseline. If not, qualification of required software will be initiated. All software will be qualified prior to completion of modeling activities. See Section 9.

All data that are to be used in support of the analysis and modeling activities must be qualified. If unqualified data or data from external sources will be used, planning for the qualification or justification for intended use is required, per LP-SIII.2Q-BSC, Qualification of Unqualified Data) or LP-SIII.10Q-BSC, Models, respectively.

\subsection{ELECTRONIC MANAGEMENT OF INFORMATION (IT-PRO-0009)}

A process control evaluation for the electronic management of information used as part of this activity was conducted and documented in accordance with Attachment 3 of IT-PRO-0009, Control of the Electronic Management of Information. The completed evaluation is attached in Appendix D.

The following methods will be used for the control of electronic management of information:

- Security and integrity of the electronic information developed during the work activity is maintained by storing the information on network drives and on hard drives of password-protected personal computers. The network drives are periodically backed up and the backups labeled and stored.

- Check sums, parity checks, or file-size comparisons will be performed by computer operating systems during data transfer and storage using commonly available software and hardware, plus established computer security mechanisms, to provide assurance of the integrity of transferred data.

- In case of manual entry or transfer of information into electronic media, visual verification by an individual other than the data-entry person will be performed to ensure error-free data transfer. The verification processes will be documented, including the date and name of the person, in the technical data record package.

- Data submitted to the Technical Data Management System will be submitted and checked for consistency in accordance with Technical Data Management System (APSIII.3Q) procedures. 
- After the transfer of records to the RPC or TDMS, integrity is maintained by RPC and TDMS access controls. Retention of records is defined by procedures specific to those organizations.

\subsection{GENERAL TRAINING/QUALIFICATION REQUIREMENTS}

Personnel will be trained to LP-SIII.10Q-BSC or equivalent superceding procedures that control the development of scientific models. Specific qualification requirements for the technical reviewer(s) performing independent model validation reviews are listed in Appendix B.

\subsection{ENVIRONMENTAL CONTROLS}

No special environmental conditions or controls are required for work described in this TWP.

\section{SOFTWARE}

Software items that will be used to carry out the work described in this TWP are listed in Table 1. All software used in support of quality-affecting activities will be controlled through Software Configuration Management, either by Bechtel SAIC, LLC or the USGS/BOR. No continuous use software will be used in support of activities covered by this TWP.

Table 1. Summary of Software Used to Support Fracture and Lithophysal Studies

\begin{tabular}{|c|c|c|c|}
\hline $\begin{array}{c}\text { Software Title and } \\
\text { Version }\end{array}$ & Qualified & $\begin{array}{l}\text { Tracking } \\
\text { Number }\end{array}$ & Purpose \\
\hline Microsoft $₫$ Excel 2003 & Exempt & NA & Data entry and add-in statistical functions. \\
\hline Microsoft $@$ Access 2003 & Exempt & NA & Data compilation and presentation. \\
\hline CorelDraw 12 & Exempt & NA & $\begin{array}{l}\text { Photo editing, tracing outlines of geologic features, and } \\
\text { annotating photographs. }\end{array}$ \\
\hline MathCad 13.0 & Exempt & NA & Performs calculation management. \\
\hline AutoCad 2004 & Exempt & NA & Graphic illustrations and drawings. \\
\hline CLUSTRAN V.1.1 & Yes & $11162-1.1-00$ & $\begin{array}{l}\text { Acquired software used to analyze fracture data. } \\
\text { Clustran was selected for its common usage in fracture } \\
\text { analysis for the geotechnical and mining industries. }\end{array}$ \\
\hline DIPS V.4.03* & Yes & $30017-V 4.03$ & $\begin{array}{l}\text { Acquired software used to generate stereographic } \\
\text { projections of fracture orientation values. }\end{array}$ \\
\hline ECRB-XYZ V.03 & Yes & 30093-V.03 & $\begin{array}{l}\text { Excel } 97 \text { spreadsheet that calculates Nevada State } \\
\text { Plane coordinates for any point on the tunnel wall for } \\
\text { the bored portion of the Cross Block Drift, used to } \\
\text { determine the location of strike and dip measurements. } \\
\text { The routine also calculates the Nevada State Plane } \\
\text { coordinates for the Cross Block Drift centerline } \\
\text { (measured at the invert). }\end{array}$ \\
\hline ESF4-XYZ V.03 & Yes & 30092 V.03 & $\begin{array}{l}\text { Excel } 97 \text { spreadsheet that calculates Nevada State } \\
\text { Plane coordinates for any point on the tunnel wall for } \\
\text { the bored portion of the Exploratory Studies Facility, } \\
\text { used to determine the location of strike and dip } \\
\text { measurements. The routine also calculates the } \\
\text { Nevada State Plane coordinates for the Exploratory } \\
\text { Studies Facility centerline (measured at the invert). }\end{array}$ \\
\hline FracMAN V.2.512 & Yes & $10114-2.511-00$ & Simulate, visualize, and identify fracture sets. \\
\hline FRACMAN XP & No & $\begin{array}{l}\text { To be } \\
\text { Determined }\end{array}$ & $\begin{array}{l}\text { New version: Simulate, visualize, and identify fracture } \\
\text { sets. }\end{array}$ \\
\hline
\end{tabular}


Table 1. Summary of Software Used to Support Fracture and Lithophysal Studies (Continued)

\begin{tabular}{|l|l|l|l|}
\hline $\begin{array}{c}\text { Software Title and } \\
\text { Version }\end{array}$ & Qualified & $\begin{array}{c}\text { Tracking } \\
\text { Number }\end{array}$ & \multicolumn{1}{c|}{ Purpose } \\
\hline FPGM_Polarcon V.02* & Yes & 10158-.02-00 & $\begin{array}{l}\text { Excel 97 spreadsheet that converts Cartesian to Polar } \\
\text { coordinates for curved portions of the Full Periphery } \\
\text { Geologic Map AutoCad drawings and calculates } \\
\text { Nevada State Plane Coordinates, used to determine } \\
\text { location of strike and dip measurements. } \\
\text { FPGM_Polarcon V.02 was modified from a previous } \\
\text { version to include data from the Cross Block Drift. }\end{array}$ \\
\hline FPGM-SD_Check V.01 & Yes & 30077 V.01 & $\begin{array}{l}\text { Unix perl script and two MS Excel 97 macros, used to } \\
\text { extract and sort fracture data from Full Periphery } \\
\text { Geologic Map AutoCad files. Checks that strike and } \\
\text { dip values are properly entered. }\end{array}$ \\
\hline READ DXF V.1.0 & Yes & $\begin{array}{l}\text { READ DXF was used to read fracture data files in DXF } \\
\text { format and extract polyline data with associated } \\
\text { strike/dip tags for input into FRACMAN. Read DXF } \\
\text { was specifically developed to extract fracture data from } \\
\text { Full Periphery Geologic Map AutoCad files to facilitate } \\
\text { the comparison of field fracture data to the synthetic } \\
\text { FRACMAN fracture data. }\end{array}$ \\
\hline Scionlmage V.4.02* & Yes & Yes & $11159-1.0-00$ \\
\hline Segment V.1.0* & Ymage analysis. \\
\hline
\end{tabular}

NOTE: $\quad$ NA = not applicable, exempt from qualification per IT-PRO-0011, Software Management.

* Denotes legacy software codes that are subject to the requirements of IT-PRO-0014.

\section{ORGANIZATIONAL INTERFACES}

The work in this TWP will be performed by the USGS/BOR.

Customer organizations are:

1) Licensing and Analysis - Regulatory Compliance, which uses the technical products in this TWP to address KTI agreements and AINs

2) Postclosure Activities - Disruptive Events, which uses the output of the technical products in this TWP to enhance the technical basis for fracture input to the drift degradation analyses.

In addition, the Postclosure Activities-Natural Systems and Near-Field Environment organizations may be potentially impacted by the results of the work described in this TWP.

Interface with the following organizations will be done to implement activities described in this TWP:

- USGS/BOR and Sandia National Laboratories will provide input data for the model as downloaded from the TDMS

- Disruptive Events organization on impact review of applicable downstream reports

- Natural Systems organization on impact review of applicable downstream reports 
- Software Management organization for software qualification and software user request processes

- TSPA organization on activities related to impact analyses.

\section{PROCUREMENT}

Three sole-source procurements will be used to support the activities of this TWP. Golder and Associates will be tasked to assist with qualifying FRACMAN XP, and assisting in the evaluation and review of the FRACMAN analyses. Black and Veatch and Dr. James Riehle will provide expertise in volcanology.

USGS personnel will use YMP-USGS-QMP-4.01, Procurement Actions, and YMP-USGSQMP-4.02 Control of Agreements for procurement activities.

\section{REFERENCES}

\subsection{DOCUMENTS CITED}

170211 BSC (Bechtel SAIC Company) 2002. Technical Work Plan for: Fracture and Lithophysal Studies. TWP-NBS-GS-000005 REV 00. Las Vegas, Nevada: Bechtel SAIC Company. ACC: MOL.20021113.0214.

168796 BSC 2003. Risk Information to Support Prioritization of Performance Assessment Models. TDR-WIS-PA-000009 REV 01 ICN 01 [Errata 001]. Las Vegas, Nevada: Bechtel SAIC Company. ACC: MOL.20021017.0045; DOC.20031014.0003.

166107 BSC 2004. Drift Degradation Analysis. ANL-EBS-MD-000027 REV 03. Las Vegas, Nevada: Bechtel SAIC Company. ACC: DOC.20040915.0010; DOC.20050419.0001; DOC.20051130.0002.

169854 BSC 2004. Thermal Conductivity of the Potential Repository Horizon. MDL-NBSGS-000005 REV 01. Las Vegas, Nevada: Bechtel SAIC Company. ACC: DOC.20040928.0006.

168706 BSC 2005. The Development of the Total System Performance Assessment-License Application Features, Events, and Processes. TDR-WIS-MD-000003 REV 01. Las Vegas, Nevada: Bechtel SAIC Company. ACC: DOC.20050214.0001.

177163 Brocoum, S. 2001. "Transmittal of U.S. Department of Energy Schedule for Responses to U.S. Nuclear Regulatory Commission (NRC) Request for Additional Information: Structural Deformation and Seismicity (SDS) Key Technical Issue (KTI) Agreements." Letter from S. Brocoum (DOE/YMSCO) to C.W. Reamer (NRC), October 30, 2001, OL\&RC:TCG-0130. ACC: MOL.20020122.0070.

152286 CRWMS M\&O 2000. Fracture Geometry Analysis for the Stratigraphic Units of the Repository Host Horizon. ANL-EBS-GE-000006 REV 00. Las Vegas, Nevada: CRWMS M\&O. ACC: MOL.20000918.0286. 
176927 DOE (U.S. Department of Energy) 2006. Quality Assurance Requirements and Description. DOE/RW-0333P, Rev. 17. Washington, D.C.: U.S. Department of Energy, Office of Civilian Radioactive Waste Management. ACC: DOC.20060504.0008.

154287 Gardner, D. 2000. "Meeting Summary, NRC/DOE Technical Exchange on Structural Deformation and Seismicity KTI, October 11-12, 2000." E-mail from D.Gardner to C. Hanlon, October 13, 2000, with attachment. ACC: MOL.20001102.0041; MOL: 20001102.0042.

177157 Kokajko, L.E. 2005. Pre-Licensing Evaluation of Key Technical Issue Agreement: Structural Deformation and Seismicity 3.03, Regarding Fracture Geometry Analysis. ACC: MOL.20050428.0005.

177187 McKague, H.L. 2000. Review of AMR Entitled "Fracture Geometry Analysis for the Stratigraphic Units of the Repository Host Horizon." Letter from H.L. McKague (CNWRA) to P. Justus (NRC), December 27, 2000, with enclosure. ACC: MOL.20060712.0210.

163274 NRC (U.S. Nuclear Regulatory Commission) 2003. Yucca Mountain Review Plan, Final Report. NUREG-1804, Rev. 2. Washington, D.C.: U.S. Nuclear Regulatory Commission, Office of Nuclear Material Safety and Safeguards. TIC: 254568.

177158 Reamer, C.W. 2001. Structural Deformation and Seismicity Key Technical Issue Agreements: Additional Information Needed. Letter Reamer to Brocoum, August 3, 2001. Washington D.C., U.S. Nuclear Regulatory Commission, 2 pages with enclosure: NRC Review of DOE Documents Pertaining to Structural Deformation and Seismicity Key Technical Issue Agreements. MOL.20011001.0306.

166615 Schlueter, J. 2000. "U.S. Nuclear Regulatory Commission/U.S. Department of Energy Technical Exchange and Management Meeting on Structural Deformation and Seismicity (October 11-12, 2000).” Letter from J. Schlueter (NRC) to S. Brocoum (DOE/YMSCO), October 27, 2000, with enclosure.

ACC: MOL.20010730.0232.

177159 Williams, N.H. 2002. "Contract No. DE-AC08-01RW12101 - Key Technical Issue (KTI) Agreement: Structural Deformation and Seismicity (SDS) 3.03." Letter from N.H. Williams (BSC) to J.D. Ziegler (DOE/ORD), June 28, 2002, TC:If-0626023130, with enclosures. ACC: MOL.20020820.0064.

177162 Ziegler, J.D. 2002. "Transmittal of Report Addressing Key Technical Issue (KTI) Agreement Item Structural Deformation and Seismicity (SDS) 3.03." Letter from J.D. Ziegler (DOE/YMSCO) to J.R. Schlueter (NRC), July 5, 2002, 0710023265, OL\&RC:TCG-1350, with enclosure. ACC: MOL.20020911.0127; MOL.20030219.0363. 


\subsection{CODES, STANDARDS, REGULATIONS, AND PROCEDURES}

173273 10 CFR 63. 2005 Energy: Disposal of High-level Radioactive Wastes in a Geological Repository at Yucca Mountain, Nevada. ACC: MOL.20050405.0118.

171341 DOE (U.S. Department of Energy) 2004. Augmented Quality Assurance Program (AQAP). DOE/RW-565, Rev. 0. Washington, D.C.: U.S. Department of Energy, Office of Civilian Radioactive Waste Management. ACC: DOC.20040813.0001.

176927 DOE (U.S. Department of Energy) 2006. Quality Assurance Requirements and Description. DOE/RW-0333P, Rev. 17. Washington, D.C.: U.S. Department of Energy, Office of Civilian Radioactive Waste Management. ACC: DOC.20060504.0008.

YMP-USGS-GP-20 Estimating Abundance of Features in Core and in Outcrop, Including Lithophysae, Spots, Clasts, and Fractures. Denver, Colorado: U.S. Geological Survey. ACC: MOL.19960129.0372.

YMP-USGS-GP-32, Underground Geologic Mapping. Denver, Colorado: U.S. Geological Survey. ACC: MOL.19980930.0086.

YMP-USGS-GP-54, Rev. 0. Rock Mass Classification, Manual or Electronic. Las Vegas, Nevada: Yucca Mountain Site Characterization Office.

ACC: MOL.19980608.0238. 
APPENDIX A

SOURCE DATA, LISTED BY DATA TRACKING NUMBER 


\section{INTENTIONALLY LEFT BLANK}




\section{A.1 SOURCE DATA, LISTED BY DATA TRACKING NUMBER}

GS950508314224.003. Provisional Results: Geotechnical Data - Full Periphery Map Data from North Ramp of the Exploratory Studies Facility, Stations 0+60 to 4+00. Submittal date: 05/24/1995.

GS960408314224.001. Provisional Results: Geotechnical Data - Full Periphery Geotechnical Maps Of The North Ramp, Exploratory Studies Facility, Station 8+00 To 10+00, Plots OA-46201, -202, -203; Geotechnical Report - Rock Mass Quality Ratings. Submittal date: 06/24/1996.

GS960408314224.003. Provisional Results: Geotechnical Data - Full-Periphery Geotechnical Maps (Drawing OA-46-204 Through -212) and Rock Mass Quality Ratings from North Ramp of the Exploratory Studies Facility, Stations $10+00$ to $18+00$. Submittal date: 08/29/1996.

GS960708314224.008. Provisional Results: Geotechnical Data for Station $30+00$ to Station 35+00, Main Drift of the ESF. Submittal date: 08/05/1996.

GS960708314224.009. Provisional Results: Geotechnical Data for Station 18+00 to 26+00, North Ramp of the ESF, Full-Periphery Geotechnical Maps and Rock Mass Quality Ratings Report. Submittal date: 09/09/1996.

GS960708314224.010. Provisional Results: Geotechnical Data for Station 40+00 to Station 45+00, Main Drift of the ESF. Submittal date: 08/05/1996.

GS960908314224.014. Provisional Results - ESF Main Drift, Station 50+00 to Station 55+00. Submittal date: 09/09/1996.

GS960908314224.015. Provisional Results: Geotechnical Data for Stations 30+00 to 40+00, Main Drift of the ESF, Full-Periphery Geotechnical Maps and Rock Mass Quality Ratings Report. Submittal date: 09/09/1996.

GS960908314224.016. Provisional Results: Geotechnical Data For Station 40+00 to 50+00, MAIN DRIFT of the ESF, Full-Periphery Geotechnical Maps and Rock Mass Quality Ratings Report. Submittal date: 09/09/1996.

GS960908314224.017. Provisional Results: Geotechnical Data for Stations 50+00 to 55+00, Main Drift of the ESF, Full-Periphery Geotechnical Maps and Rock Mass Quality Ratings Report. Submittal date: 09/09/1996.

GS960908314224.020. Analysis Report: Geology of the North Ramp - Stations 4+00 to 28+00 and Data: Detailed Line Survey and Full-Periphery Geotechnical Map - Alcoves 3 (UPCA) and 4 (LPCA), and Comparative Geologic Cross Section - Stations 0+60 to 28+00. Submittal date: 09/09/1996.

GS970108314224.002. Geotechnical Data for Station 55+00 to Station 60+00, Main Drift of the ESF, Full Periphery Geotechnical Maps. Submittal date: 01/31/1997. 
GS970208314224.003. Geotechnical Data for Station 60+00 to Station 65+00, SOUTH RAMP of the ESF. Submittal date: 02/12/1997.

GS970208314224.004. Geotechnical Data for Station 60+00 to Station 65+00, South Ramp of the ESF. Submittal date: 02/12/1997.

GS970608314224.007. Provisional Results: Geotechnical Data for the Exploratory Studies Facility. Main Drift, Alcove 5 (DWFA): Heated Drift and Cross Drift Full Periphery Geotechnical Map (Drawing OA-46-300) and Rock Mass Quality Ratings Report. Submittal date: $06 / 24 / 1997$.

GS970808314224.009. Provisional Results: Geotechnical Data for Station 65+00 to Station 70+00, South Ramp of the ESF; Full-Periphery Geotechnical Maps (Drawings OA-46-269 THROUGH OA-46-274) and Rock Mass Quality Ratings Report. Submittal date: 08/18/1997.

GS970808314224.010. Provisional Results: Geotechnical Data for Station $70+00$ to Station 75+00, South Ramp of the ESF. Submittal date: 08/25/1997.

GS970808314224.011. Full-Periphery Geotechnical Maps (Drawings OA-46-275 through OA46-280) and Rock Mass Quality Ratings Report. Submittal date: 08/25/1997.

GS970808314224.013. Provisional Results: Geotechnical Data for Station $75+00$ to Station 78+37, South Ramp of the ESF. Submittal date: 08/25/1997.

GS971108314224.025. Revision 1 of Detailed Line Survey Data, Station 26+00 to Station 30+00, North Ramp and Main Drift, Exploratory Studies Facility. Submittal date: 12/03/1997.

GS971108314224.028. Revision 1 of Detailed Line Survey Data, Station 55+00 to Station 60+00, Main Drift and South Ramp, Exploratory Studies Facility. Submittal date: 12/03/1997.

GS990408314224.001. Detailed Line Survey Data for Stations 00+00.89 to 14+95.18, ECRB Cross Drift. Submittal date: 09/09/1999.

GS990408314224.002. Detailed Line Survey Data for Stations $15+00.85$ to $26+63.85$, ECRB Cross Drift. Submittal date: 09/09/1999.

GS990408314224.003. Full-Periphery Geologic Maps for Station- 0+10 to 10+00, ECRB Cross Drift. Submittal date: 09/09/1999.

GS990408314224.004. Full-Periphery Geologic Maps for Station 10+00 to 15+00, ECRB cross drift. Submittal date: 09/09/1999.

GS990408314224.005. Full-Periphery Geologic Maps for Station 15+00 to 20+00, ECRB Cross Drift. Submittal date: 09/09/1999.

GS990408314224.006. Full-Periphery Geologic Maps for Station 20+00 to 26+81, ECRB Cross Drift. Submittal date: 09/09/1999. 
APPENDIX B

PLANNING FOR TECHNICAL REVIEWS FOR PURPOSES OF MODEL VALIDATION 
INTENTIONALLY LEFT BLANK 


\section{APPENDIX B. PLANNING FOR TECHNICAL REVIEWS FOR PURPOSES OF MODEL VALIDATION}

\section{B.1 MODELS USING TECHNICAL REVIEW AS A VALIDATION METHOD}

The Responsible Manager has elected to use an independent technical review as a method for model validation for activities described in this TWP. The model has four components as follows:

- A discrete fracture network of the Topopah Spring Tuff Crystal Poor Upper Lithophysal Zone (Tptpul)

- A discrete fracture network of the Topopah Spring Tuff Crystal Poor Middle Non Lithophysal Zone (Tptpmn)

- A discrete fracture network of the Topopah Spring Tuff Crystal Poor Lower Lithophysal Zone (Tptpll)

- A discrete fracture network of the Topopah Spring Tuff Crystal Poor Lower Non Lithophysal Zone (Tptpln).

\section{B.2 SELECTION OF TECHNICAL REVIEWERS}

The model will utilize a technical review as a method of postdevelopment model validation per LP-SIII.10Q-BSC, Section 5.3.2. The general requirements for the model validation technical reviewer, and for conduct of the review are provided in Section 2.5.3.

\section{B.3 SPECIFIC QUALIFICATION AND SELECTION CRITERIA FOR TECHNICAL REVIEWERS}

\section{B.3.1 Discrete Fracture Network model of the repository host horizon (Tptpul, Tptpmn , Tptpll, Tptpln)}

Documented experience in the evaluation of discontinuities as they relate to fractured rock masses. Individual must, at a minimum, possess an undergraduate degree in geology or strongly related field. Experience with field mapping of fracture attributes is also required.

- Minimum of five years of experience in mapping.

- Experience with construction of discrete fracture network models.

\section{B.4 SPECIFIC REVIEW CRITERIA}

The specific criteria for each of the models are described in Section 2.5.5. 


\section{B.5 TECHNICAL REVIEW DOCUMENTATION}

The decision for selecting the technical reviewer and the results of the review will be documented in the appropriate model reports, as outlined above. 


\section{APPENDIX C \\ YMRP ACCEPTANCE CRITERIA APPLICABLE TO ACTIVITIES RELATED TO TWP-NBS-GS-000005}


INTENTIONALLY LEFT BLANK 
Table C-1. YMRP Acceptance Criteria Applicable to Activities Related to TWP-NBS-GS-000005

\begin{tabular}{|c|c|}
\hline Acceptance Criterion & Summary \\
\hline \multicolumn{2}{|l|}{ Section 1.5 .3} \\
\hline$A C 1(1)$ & $\begin{array}{l}\text { Report describes fracture characteristics of host horizon and thereby contributes } \\
\text { to the description of the geological aspects of the host rock. }\end{array}$ \\
\hline$A C 2(1)$ & $\begin{array}{l}\text { Report describes fracture characteristics and fracturing of host horizon and } \\
\text { thereby contributes to the understanding of the features and processes present at } \\
\text { YM. }\end{array}$ \\
\hline$A C 2(2)$ & $\begin{array}{l}\text { Report describes fracture characteristics and fracturing of host horizon and } \\
\text { thereby contributes to the understanding of the features and processes present at } \\
\text { YM. }\end{array}$ \\
\hline $\mathrm{AC} 2(3)$ & Not addressed \\
\hline \multicolumn{2}{|l|}{ Section 2.2.1.3.2.3 } \\
\hline $\mathrm{AC} 1(1)$ & $\begin{array}{l}\text { Report provides information about fracture characteristics but does not address } \\
\text { potential couplings }\end{array}$ \\
\hline$A C 1(2)$ & $\begin{array}{l}\text { Report describes fracture characteristics of host horizon and thereby contributes } \\
\text { to the description of the geological aspects of the host rock. }\end{array}$ \\
\hline$A C 1(3)$ & $\begin{array}{l}\text { Not directly addressed. Report describes fracture characteristics of host horizon } \\
\text { that are used in the drift degradation analysis (BSC } 2004 \text { [DIRS 166107]) }\end{array}$ \\
\hline $\mathrm{AC} 1(4)$ & Not addressed \\
\hline $\mathrm{AC} 1(5)$ & Report describes fracture characteristics of host horizon \\
\hline $\mathrm{AC} 1(6)$ & Not addressed \\
\hline $\mathrm{AC} 1(7)$ & Not addressed unless some existing data is qualified in the report. \\
\hline$A C 2(1)$ & $\begin{array}{l}\text { Report describes fracture characteristics of host horizon and thereby contributes } \\
\text { to the description of the geological aspects of the host rock. }\end{array}$ \\
\hline$A C 2(2)$ & $\begin{array}{l}\text { Report describes fracture characteristics of host horizon and thereby contributes } \\
\text { to the description of the geological aspects of the host rock. }\end{array}$ \\
\hline $\mathrm{AC} 2(3)$ & Not addressed. Report provides no abstraction to TSPA \\
\hline $\mathrm{AC} 2(4)$ & Not addressed. Report does not describe mechanical failure models \\
\hline $\mathrm{AC} 3(1)$ & $\begin{array}{l}\text { Report describes fracture characteristics of host horizon and thereby contributes } \\
\text { to the development of fracture parameters for the host rock. }\end{array}$ \\
\hline$A C 3(2)$ & $\begin{array}{l}\text { Report describes fracture characteristics of host horizon and thereby contributes } \\
\text { to the development of fracture parameters for the host rock. }\end{array}$ \\
\hline $\mathrm{AC} 3(3)$ & $\begin{array}{l}\text { Report describes fracture characteristics of host horizon, including uncertainties in } \\
\text { the fracture data, and thereby contributes to the description of the geological } \\
\text { aspects of the host rock. }\end{array}$ \\
\hline $\mathrm{AC} 3(4)$ & Not addressed; expert elicitation not used \\
\hline $\mathrm{AC} 4(1)$ & $\begin{array}{l}\text { Report describes alternative methods used to model fractures and fracturing in } \\
\text { the host horizon. }\end{array}$ \\
\hline$A C 4(2)$ & $\begin{array}{l}\text { Report describes uncertainty in the conceptual model(s) used to describe } \\
\text { uncertainties in fractures in the host horizon. }\end{array}$ \\
\hline $\mathrm{AC} 4(3)$ & $\begin{array}{l}\text { Report describes alternative methods used to model fractures and fracturing in } \\
\text { the host horizon and why those models are appropriate for modeling fractures at } \\
\text { YM. }\end{array}$ \\
\hline $\mathrm{AC} 5(1)$ & Not addressed; report provides no abstraction to TSPA \\
\hline $\mathrm{AC} 5(2)$ & Not addressed; report provides no abstraction to TSPA \\
\hline AC 5(3) & $\begin{array}{l}\text { Methods used to validate the fracture model (or other models) are described in } \\
\text { Section 2.5. }\end{array}$ \\
\hline$A C 5(4)$ & Not addressed; report describes only site fracture data. \\
\hline
\end{tabular}


Table C-1. YMRP Acceptance Criteria Applicable to Activities Related to TWP-NBS-GS-000005 (Continued)

\begin{tabular}{|c|c|}
\hline Acceptance Criterion & Summary \\
\hline Section 2.2.1.3.6.3 & \\
\hline AC 1(1) & $\begin{array}{l}\text { Report describes fracture characteristics of host horizon and thereby contributes } \\
\text { to the description of the geological aspects of the host rock, but the report does } \\
\text { not provide abstractions for TSPA nor describe how those abstractions might be } \\
\text { incorporated in TSPA. }\end{array}$ \\
\hline AC 1(2) & $\begin{array}{l}\text { Report describes fracture characteristics of host horizon and thereby contributes } \\
\text { to the description of the geological aspects of the host rock. }\end{array}$ \\
\hline AC 1(3) & $\begin{array}{l}\text { Report does not address description of flow paths or the development of the flow } \\
\text { path abstraction for TSPA }\end{array}$ \\
\hline AC 1(4) & Report does not address radionuclide transport. \\
\hline AC 1(5) & $\begin{array}{l}\text { Report describes fracture and lithophysae characteristics of the host rock but } \\
\text { does not produce abstractions for TSPA }\end{array}$ \\
\hline AC 1(6) & $\begin{array}{l}\text { Not addressed; report does not describe flow parameters used in the UZ flow } \\
\text { model. }\end{array}$ \\
\hline AC $1(7)$ & $\begin{array}{l}\text { Not addressed; report does not describe average flow parameters used in the UZ } \\
\text { flow model. }\end{array}$ \\
\hline AC $1(8)$ & Not addressed \\
\hline AC 1(9) & Not addressed unless existing data related to UZ flow model is qualified in report \\
\hline AC 2(1) & $\begin{array}{l}\text { Report describes fracture characteristics of host horizon and thereby contributes } \\
\text { to the description of the geological aspects of the host rock, but the report does } \\
\text { not address hydrological or thermal-hydrological-mechanical-chemical values. }\end{array}$ \\
\hline AC 2(2) & $\begin{array}{l}\text { Report describes the collection and modeling of fracture characteristics of host } \\
\text { horizon and thereby contributes to the description of the geological aspects of the } \\
\text { host rock }\end{array}$ \\
\hline AC 2(3) & Not addressed. \\
\hline AC 2(4) & Not addressed \\
\hline AC 2(5) & $\begin{array}{l}\text { Report describes fracture characteristics of host horizon but does not address } \\
\text { sensitivity or uncertainty analyses related to flow paths }\end{array}$ \\
\hline AC 2(6) & $\begin{array}{l}\text { Report describes calibration of the fracture model, but does not address } \\
\text { development and calibration of flow path models }\end{array}$ \\
\hline AC 2(7) & $\begin{array}{l}\text { Report describes fracture characteristics of host horizon but does not address } \\
\text { development of conceptual or mathematical models related to flow paths }\end{array}$ \\
\hline AC 2(8) & Not addressed; expert elicitation not used \\
\hline AC 3(1) & $\begin{array}{l}\text { Report describes fracture characteristics but does not develop an abstraction for } \\
\text { TSPA }\end{array}$ \\
\hline AC 3(2) & Not addressed; report does not develop an abstraction for TSPA \\
\hline AC 3(3) & Not addressed; report does not develop an abstraction for TSPA \\
\hline AC 3(4) & $\begin{array}{l}\text { Report describes fractures and fracturing in the host rock and provides the basis } \\
\text { to develop fracture parameters, but the report does not develop an abstraction for } \\
\text { TSPA }\end{array}$ \\
\hline
\end{tabular}


Table C-1. YMRP Acceptance Criteria Applicable to Activities Related to TWP-NBS-GS-000005 (Continued)

\begin{tabular}{|c|c|}
\hline Acceptance Criterion & Summary \\
\hline Section 2.2.1.3.6.3 & \\
\hline AC 3(5) & $\begin{array}{l}\text { Report describes fractures and fracturing in the host rock; coupled processes are } \\
\text { not addressed }\end{array}$ \\
\hline AC 3(6) & $\begin{array}{l}\text { Report describes fractures and fracturing in the host rock including uncertainties } \\
\text { in the data, but the report does not develop an abstraction for TSPA }\end{array}$ \\
\hline AC $4(1)$ & $\begin{array}{l}\text { Report describes alternative methods used to model fractures and fracturing in } \\
\text { the host rock }\end{array}$ \\
\hline AC $4(2)$ & $\begin{array}{l}\text { Not addressed. Report describes characteristics of fractures and fracturing but } \\
\text { does not produce an abstraction for TSPA (Author needs to modify depending on } \\
\text { the nature of any abstraction and what the abstraction is used for.) }\end{array}$ \\
\hline AC 4(3) & $\begin{array}{l}\text { Report describes characteristics of fractures and fracturing. Risk estimation is not } \\
\text { addressed in this report. }\end{array}$ \\
\hline AC 5(1) & Not addressed; report does not produce an abstraction for TSPA \\
\hline AC 5(2) & $\begin{array}{l}\text { Not addressed. Report describes characteristics of fractures and fracturing but } \\
\text { does not produce an abstraction for TSPA (Author needs to modify depending on } \\
\text { the nature of any abstraction and what the abstraction is used for.) }\end{array}$ \\
\hline AC 5(3) & $\begin{array}{l}\text { Not addressed; report does not produce outputs of abstracted models of flow } \\
\text { paths. }\end{array}$ \\
\hline
\end{tabular}




\section{INTENTIONALLY LEFT BLANK}




\section{APPENDIX D}

PROCESS CONTROL EVALUATION FOR THE ELECTRONIC MANAGEMENT OF INFORMATION 
INTENTIONALLY LEFT BLANK 


\section{Process Control Evaluation for the Electronic Management of Information}

Complete only applicable items.

\section{A. Procedure/Work Activity Identification (check one) \\ $\square$ Procedure (identify process procedure number, title, revision and ICN level being evaluated), or}

W Work Activity (identify by work package number, Technical Work Plan, technical product, etc., including title and revision)

Technical Work Plan for: Fracture and Lithophysal Studies, TWP-NBS-GS-000005 Rev.01 ICN00

\section{B1. Processes/Process Functions/Work Activities Evaluation}

\begin{tabular}{|c|c|c|c|}
\hline & & Yes & No \\
\hline & $\begin{array}{l}\text { Will, or does, the process/process function/work activity depend on a form of electronic media to store, maintain, retrieve, modify, } \\
\text { update, or transmit information? }\end{array}$ & $\bigotimes$ & $\square$ \\
\hline 2. & $\begin{array}{l}\text { Will, or does, the process/process function/work activity manage, control, or use an electronic database, spreadsheet, set of files, } \\
\text { or other holding system for information? }\end{array}$ & 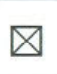 & $\square$ \\
\hline 3. & $\begin{array}{l}\text { Will, or does, the process/process function/work activity transfer information electronically from one location to another? (The } \\
\text { method may be File Transfer Protocol, electronic download, tape to tape, disk to disk, etc.) }\end{array}$ & $\bigotimes$ & 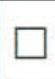 \\
\hline 4. & Will, or does, the process/process function/work activity produce any Sensitive Unclassified electronic information? & $\square$ & 冈 \\
\hline
\end{tabular}

\section{B2. Processes/Process Functions/Work Activities Compliance Evaluation}

1. If any Sensitive Unclassified electronic information is produced, are the process controls in accordance with AP-SEC-001?

2. Does the procedure or work activity document provide adequate controls to protect information from damage and destruction for its prescribed lifetime?

3. Does the procedure or work activity document provide adequate controls to ensure that information is readily retrievable?

4. Does the procedure or work activity document provide adequate controls to describe how information will be stored with respect to media, conditions, location, retention time, security, and access?

5. Does the procedure or work activity document provide adequate controls to properly identify storage and transfer media as to source, physical and logical format, and relevant date?

6. Does the procedure or work activity document provide adequate controls to ensure completeness and accuracy of the information input and any subsequent changes?

7. Does the procedure or work activity document provide adequate access to controls to maintain the security and integrity of the information?

8. Does the procedure or work activity document provide adequate controls to ensure that transfers are error free or within a defined permissible error rate? (e.g., copying raw information from notebook to electronic information form, electronic media to another electronic media, or File Transfer Protocols)

If a "No" answer is given for any question in Section B2, proceed to Section C; otherwise process in accordance with Step 4.1.2.7. Mark "N/A" for those items that are not applicable to the specific process or work activity.

\section{Results of Evaluation}

Provide a summary of the "as-is condition," proposed remedial actions, and expected completion date of document revision, for each item in Section B2 that was indicated as "No."
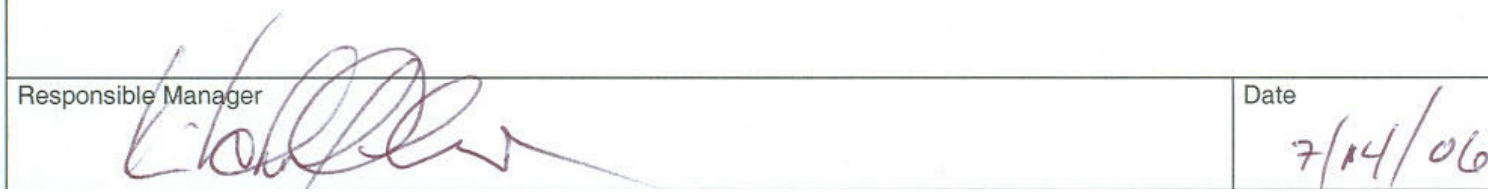
INTENTIONALLY LEFT BLANK 